\title{
Ainda sobre indexações
}

\author{
Harley E. A. Bicas, Edna T. Rother, Maria Elisa R. Braga
}

Em nosso editorial mais recente, foi orgulhosamente saudado o ingresso dos Arquivos Brasileiros de Oftalmologia no seleto grupo de periódicos acolhidos pela SciELO, a "Scientific Electronic Library Online" (Biblioteca Científica Eletrônica em Linha), uma realização da Fundação de Amparo à Pesquisa do Estado de São Paulo (F.A.P.E.S.P.) e do Centro Latino-Americano e do Caribe de Informação em Ciências da Saúde (BIREME). Recém-criada (1997) e operando regularmente desde o ano seguinte, a rede SciELO é um modelo para a publicação eletrônica cooperativa de periódicos científicos na Internet. Especialmente concebida para responder às necessidades de comunicação científica nos países em desenvolvimento, particularmente da América Latina e Caribe, mas já se estendendo aos países da península ibérica, a SciELO proporciona uma solução para assegurar a visibilidade e o acesso universal à literatura científica de nossas comunidades, contribuindo para o resgate de suas "ciências perdidas". Com justo respeito, representa um dos mais expressivos e vitoriosos modelos de organização e eficiência na promoção e reconhecimento internacional de publicações científicas meritórias.

Com efeito, os temas das indexações, da visibilidade das publicações, da "ciência perdida", o de uso de índices bibliométricos, atualíssimos, tornaram-se relevantes para autores e vitais para as revistas científicas. Um exemplo dessas importâncias vem da ênfase que lhes é dada por nossas Universidades (para a avaliação de desempenhos acadêmicos) e pelas agências de fomento à pesquisa científica nacional (para avaliação dessas instituições e de seus docentes). Por outro lado, há vigorosos questionamentos sobre como a assunção dessas noções de validação de trabalhos tem sido pouco criticada por seus aplicadores. De fato, tanto pela relativa novidade com que se faz uso desses conceitos e critérios, quanto pelas conseqüências originadas das complexidades de seus gerenciamentos, o assunto é, no mínimo, polêmico, além de extenso. Quando cursos de pós-graduação ficam monitorados por "fatores de impacto", "publicações indexadas" e que tais; quando acadêmicos também passam a ter suas competências e desempenhos universitários medidos por idênticos parâmetros; quando os valores de órgãos de publicação tornam-se igualmente subordinados ao império desses quesitos, parece oportuníssimo ampliar a discussão sobre eles. Mas pela amplitude dos assuntos, digressões sobre "fatores de impacto" e demais índices bibliométricos devem ficar para oportunidade posterior, começando-se agora com um aprofundamento sobre as "indexações" e publicidades dos artigos, seus autores e periódicos em "bases de dados." Convém então uma reintrodução preparatória aos não iniciados nessa terminologia biblioteconômica, com um esboço dos principais aspectos temáticos.
A bibliometria é parte de uma metaciência, a cienciometria, concebida por um historiador do conhecimento, Derek de Solla Price, que propôs leis de caráter genérico e métodos que pudessem aferir a produção científica e tecnológica. É inegável que a "ciência das ciências" tenha extensa aplicabilidade, ao oferecer informações sobre quantidades de titulações acadêmicas, artigos publicados, citações neles feitas ou recebidas, pessoas que os assinam, patentes registradas, etc., daí subsidiando decisões sobre políticas de fomento à ciência, avaliação de programas, etc. Tais indicadores da atividade científica e de seus resultados ("impactos" e outros conceitos) tornam-se conhecidos quase que apenas por suas expressões diretas em publicações, daí a bibliometria.

Talvez se possa dizer que a bibliometria tenha sido fundada por Eugene Garfield, Diretor do Institute for Scientific Information (I.S.I.) ao mencionar a idéia de um "fator de impacto" (1955) das publicações. De qualquer modo, já se subentendia a idéia de análise da produção científica por meio de dados de periódicos que obedecessem certos padrões de qualidade, tais como o de regularidade de publicação (em seus aspectos de periodicidade e apresentação), o da diversidade e independência do corpo editorial e o da rigorosa revisão prévia dos artigos submetidos por pares (semelhantes) de seus autores, a "peer review". Um conceito (de análise de produção científica) que implicava a indexação (reconhecimento) do periódico pelo órgão de informações ("base de dados") que as oferecia.

Em sentido restrito, a "base de dados" é terminologia hoje aplicada a órgãos nacionais e internacionais que selecionam e indexam referências de artigos com ou sem resumos. Podem aparecer em forma impressa ou em apresentação eletrônica, eventualmente disponibilizando os artigos em suas totalidades pela rede mundial de computadores. Como uma biblioteca tradicional que não pode (por espaço e por economia) conter toda e qualquer informação publicada, tantas são elas, a biblioteca eletrônica, ou os bancos de dados, especializaram-se na seleção daquilo que consideram melhor e mais apropriado para o interesse da respectiva comunidade. Transformaram-se em "indexadores". Um dos indexadores mundiais específicos mais respeitados por sua excelência é o do I.S.I.. No Brasil, o padrão de confiabilidade é representado pela SciELO.

Para um periódico, a indexação num desses órgãos é reconhecimento de mérito, aval à qualidade de seus artigos. Idem para um autor, cuja publicação fica acessível, com maior "visibilidade" por essa divulgação, recebendo validação científica, credibilidade. Um privilégio. Em princípio, pois, nada deveria ser cogitado contra a conveniência de se exigir "indexações" para as publicações de uma pessoa (o que até explica a tendência, cada vez mais pronunciada, em Universidades e agências de fomento à pesquisa científica nacional, para aquilatar 
desempenhos acadêmicos). Entretanto, os alcances dessa política são muito amplos e se trazem benefícios em vários aspectos, em muitos outros são nocivos.

Um fator positivo, por exemplo, é o da pressão exercida tanto sobre periódicos (para que melhorem suas qualidades editoriais) quanto sobre autores (para que se submetam a critérios de seleção mais rigorosos, supostamente encontrados nas revistas indexadas). Na prática, as condições e consequiências não são tão simples. Para a indexação de uma revista podem prevalecer interesses culturais, políticos e geográficos. Assim, por exemplo, com base em que espaços são limitados, quer em papel, quer em hiper-textos, ocorreria uma baixa conveniência e quase desinteresse de um indexador latino-americano apresentar artigos de uma publicação em quirguiz. Como, também, revistas em português seriam mais facilmente discriminadas nas injunções que órgãos anglo-saxônicos estabelecem para suas seleções. Chega a ser compreensível. Que tal, então, publicar numa língua "universal" como o inglês ? A solução não é boa: duplicar a apresentação do artigo, mantendo-o também na língua original do país, é oneroso. Fazê-lo apenas na língua "universal" equivale a supor que todos os leitores tenham intimidades com ela, o que nem sempre é verdade; principalmente quando o periódico não se destina apenas à divulgação da ciência "de ponta" (uma circunstância que poderia ter como premissa que todo cientista deva saber inglês) mas, também, à atualização e aprofundamento dos conhecimentos profissionais. E justamente o contingente desses leitores que, teoricamente, estaria mais necessitado dos benefícios e facilidades trazidas por esse órgão (de nação como o Brasil) é o que seria desqualificado para sua leitura, fechando um círculo vicioso, elitista e concentrador de saber.

Já para um autor, a busca exclusiva ou prioritária de produ- ção para "publicações internacionais" conduz-lhe ao vício de orientar sua pesquisa e estudo para os assuntos que mais interessam aos respectivos periódicos (e seus órgãos de indexações) e não necessariamente aos conhecimentos que solucionem problemas emergenciais à sua volta. Por exemplo, com respeito a um certo tratamento, alguém imagina que um estudo mais direcionado a questões específicas de um país (como o que comprova a adoção de política sanitária de menores custos sociais, ainda que com medicamentos pouco eficazes) possa prevalecer, fora desse país, sobre outro artigo, de cunho experimental (mais "científico") e mais adequado ao interesse das sociedades e civilizações cujos indexadores a elas pertencem ? No fundo uma questão de pragmatismo: o do autor, servindo à "ciência" (leia-se "ação determinada por requerimentos socioeconômicos") das revistas internacionais e seus indexadores; ou o do país que lhe dá guarida e sustento, mas cujas necessidades podem ser bem outras. Em suma: ciência também tem política e o que convém saber é em que tipo de conhecimentos se deva investir, qual deles incentivar. E, nesse ponto, nem sempre o artigo "para inglês ver" será o mais útil a uma (nossa) nação.

De qualquer modo, sem sacrifícios de identidade ou de propósitos, os A.B.O. estão empenhados na consolidação de sua maior visibilidade e na conquista de reconhecimento de outras bases de dados internacionais (um processo lento e apenas começado). Principalmente para com isso podermos oferecer à comunidade oftalmológica nacional a opção de não precisar, eventualmente, desviar-se de objetivos que mais nos dizem respeito. Ou de não ser constrangida a satisfazer critérios de aplicabilidade ambígua, pois desmerecem esforços da editoração científica nacional emergente, favorecendo a estrangeira, já consolidada.

\section{CONGRESSO DA SOCIEDADE BRASILEIRA DE RETINA E VÍTREO}

\section{FÓRUM DO GRUPO LATINO-AMERICANO DE ANGIOGRAFIA OCULAR, FOTOCOAGULAÇÃO E CIRURGIA VITREORRETINIANA - GLADAOF}

\section{A 25 DE MAIO DE 2002 GRAN MELIÁ HOTEL - SÃO PAULO - SP}

\section{Informações: Meeting Eventos}

tels.: (11) 5511-3849 / 0379 / 8263 • fax: (11) 5511-3845 / 6818 e-mail: info@meetingeventos.com.br • home page: www.meetingeventos.com.br 